\title{
Analysis of Flavonoid Levels in Extract of Gambas Fruit (Luffa acutangula L) Originating from the Village of Posona District Parigi Moutong
}

\author{
*Aharudin, Kasmudin Mustapa \& Minarni Rama Jura \\ Pendidikan Kimia/FKIP - Universitas Tadulako, Palu - Indonesia 94119 \\ Received 17 March 2020, Revised 16 April 2020, Accepted 19 May 2020 \\ doi: 10.22487/j24775185.2020.v9.i2.pp102-106
}

\begin{abstract}
Gambas fruit (Luffa acutangula L) is a cultivable plant. Gambas fruit can be used as an alternative free radical antidote. The purpose of this study was to determine the level of flavonoids in extract of gambas fruit (Luffa acutangula L) originated from Posona village of Parigi Moutong Regency. This research uses UV-Vis spectrofotometry analysis method. Flavonoids test was done by extracting the sample using $1 \% \mathrm{HCl}$ solvent in ethanol. The result of the experiment showed that flavonoid level on the fruit of gambas (Luffa acutangula L.) was young gambas $10.60 \mathrm{mg} / 100 \mathrm{~g}$ and old gambas 2.62 $m g / 100 g$.
\end{abstract}

Keywords: Flavonoid, gambas fruit (Luffa acutangula L), spektrofotometri UV-Vis

\section{Pendahuluan}

Indonesia adalah negara yang kaya akan sumber daya alam misalnya buah dan sayuran yang mempunyai kandungan atau senyawa kimia yang dapat berguna bagi tubuh. Sayuran merupakan bahan pangan yang berasal dari tumbuhan yang memiliki kandungan air tinggi. Sayuran memilki manfaat bagi tubuh, diantaranya sebagai sumber vitamin dan serat serta yang terpenting adalah menopang kehidupan manusia agar tubuh tetap sehat (Menon, dkk., 2017). Selain mengandung vitamin dan serat sayuran juga mengandung senyawa aktif seperti senyawa golongan flavonoid, golongan alkaloid, golongan terpenoid dan lain-lain. Salah satu sayuran yang mengandung senyawa-senyawa aktif tersebut adalah gambas (Jyothi, dkk., 2010).

Tanaman gambas banyak dibudidayakan sebagai tanaman sela pekarangan dan di sawah setelah tanaman padi. Pemanfaatan buah gambas dapat dipakai sebagai sayuran untuk dibuat masakan dan daun tanaman gambas dipakai sebagai sayuran lalapan (Tristayanto, 2009). Selaian dikonsumsi buah gambas juga digunakan sebagai obat dimana dalam bentuk segar digunakan untuk pemeriksaan makroskopik dan mikroskopik dan dalam bentuk serbuk digunakan untuk pemeriksaan histochemical, behavior dan fitochemical (Sigit, dkk., 2016). Hasil observasi di desa Posona kabupaten Parigi Moutong bahwa masyarakat desa Posona umumnya memanfaatkan gambas muda sebagai sayuran sedangkan gambas tua dibiarkan begitu saja hingga kering tanpa dimanfaatkan secara optimal.

Buah gambas diketahui mengandung banyak senyawa-senyawa kimia yang berguna untuk kesehatan. Adapun kandungan kimia dari buah gambas yaitu karbohidrat, karoten, lemak, protein, asamamino, alanin, arginin, glisin, cystin, asam glutamat, hidroksiprolin, leusin, serin, triptopan, flavonoid dan saponin (Jyothi, dkk., 2010). Rebusan buah gambas yang ditambah garam dapat digunakan untuk melancarkan sistem pencernaan, biji gambas yang mengandung minyak banyak digunakan untuk perawatan kulit, daun dari tanaman gambas dapat digunakan untuk mengobati penyakit disentri sedangkan bagian akarnya digunakan untuk meluruhkan batu ginjal (Shrivastava \& Roy, 2013).

Antioksidan merupakan senyawa yang dapat menghambat reaksi oksidasi, dengan mengikat radikal bebas dan molekul yang sangat reaktif. Antioksidan juga mampu menginaktivasi berkembangnya reaksi oksidasi dengan cara mencegah terbentuknya radikal bebas (Winarsi, 2007). Radikal bebas yang merusak tubuh dapat dinetralisir oleh senyawa antioksidan, senyawa antioksidan dapat menghambat oksigen reaktif dan radikal bebas didalam tubuh. Senyawa antioksidan akan menyerahkan satu atau lebih elektron kepada senyawa radikal bebas sehingga menjadi bentuk molekul yang normal kembali dan menghentikan kerusakan yang akan ditimbulkan (Redha, 2010).

${ }^{*}$ Correspondence:

Aharudin

e-mail: aharudin072@gmail.com

(c) 2020 the Author(s) retain the copyright of this article. This article is published under the terms of the Creative Commons Attribution License 4.0, which permits unrestricted non-commercial use, distribution, and reproduction in any medium, provided the original work is properly cited. 
Flavonoid merupakan salah satu kelompok senyawa metabolit sekunder yang paling banyak ditemukan di dalam jaringan tanaman. Senyawa flavonoid adalah salah satu antioksidan yang sangat efektif karena radikal bebasnya yang aktif (Knekt, dkk., 2002). Flavonoid dikenal memiliki sifat sebagai antioksidan, antiinflamasi, antifungsi, antiviral, antikanker dan antibakteri (Wijaya, dkk., 2014). Berdasarkan hasil-hasil penelitian yang telah dilakukan, diyakini bahwa flavonoid sebagai salah satu kelompok senyawa fenolik yang memiliki sifat antioksidatif serta berperan dalam mencegah kerusakan sel dan komponen selularnya oleh radikal bebas reaktif (Redha, 2010).

Flavonoid merupakan salah satu kelompok senyawa metabolit sekunder yang paling banyak ditemukan di dalam jaringan tanaman. Senyawa flavonoid adalah salah satu antioksidan yang sangat efektif karena radikal bebasnya yang aktif (Knekt, dkk., 2002). Flavonoid dikenal memiliki sifat sebagai antioksidan, antiinflamasi, antifungsi, antiviral, antikanker dan antibakteri (Wijaya, dkk., 2014). Berdasarkan hasil-hasil penelitian yang telah dilakukan, diyakini bahwa flavonoid sebagai salah satu kelompok senyawa fenolik yang memiliki sifat antioksidatif serta berperan dalam mencegah kerusakan sel dan komponen selularnya oleh radikal bebas reaktif (Redha, 2010).

Tulisan ini bertujuan untuk menganalisis kadar flavonoid pada ekstrak buah gambas (Luffa acutangula L) yang berasal dari desa Posona kabupaten Parigi Moutong.

\section{Metode}

Sampel yang digunakan pada penenelitian ini adalah buah gambas muda dan tua yang berasal dari desa Posona kabupaten Parigi Moutong.

Alat-alat yang digunakan pada penelitian ini yaitu gelas ukur, labu ukur, labu ukur, erlenmeyer, pipet tetes, gelas kimia, tabung reaksi, oven, corong, mesin seker, neraca digital, spatula, blender dan spektrometri UV-Vis.

Bahan yang digunakan pada penelitian ini yaitu serbuk buah gambas muda dan gambas tua yang berasal dari desa Posona kabupaten Parigi Moutong, larutan $\mathrm{HCl}$ pekat, larutan etanol, kertas saring, larutan buffer $\mathrm{pH} 1$ dan $\mathrm{pH}$ 4.5.

\section{Preparasi Sampel}

Sampel buah gambas dicuci hingga bersih lalu sampel dipotong menjadi kecil-kecil kemudian diangin-anginkan hingga kering. Setelah sampel kering, selanjutnya sampel dihaluskan dengan menggunakan blender.

\section{Analisis Kadar Air}

Buah gambas muda dan gambas tua dibersihkan kemudian dipotong kecil-kecil lalu ditimbang dan dimasukkan ke dalam wadah, lalu dipanaskan dalam oven pada suhu $105^{\circ} \mathrm{C}$ selama \pm 1 jam, kemudian didinginkan dalam desikator dalam selang waktu 30 menit setelah pemanasan dan ditimbang kemudian dilakukan kembali secara berulang-ulang hingga diperoleh berat konstan. Kemudian ditentukan kadar airnya dengan rumus sebagai berikut (Sudarmadji, dkk., 1989):

$$
\text { Kadar air }=\frac{\text { Berat Awal-Berat Akhir }}{\text { Berat Awal }} \times 100 \%
$$

\section{Analisis Kadar Flavonoid}

Mengambil sebanyak 20 gram bubuk sampel dan dimasukkan ke dalam erlenmeyer kemudian mengekstraksi dengan menggunakan metode ekstraksi maserasi dengan cara menambahkan pelarut $\mathrm{HCl} 1 \%$ dalam etanol sebanyak $200 \mathrm{~mL}$ ke dalam erlenmeyer yang telah terisi bubuk sampel lalu dikocok campuran dengan menggunakan mesin shaker pada kecepatan $160 \mathrm{rpm}$ selama 1 jam setelah itu dimaserasi selama 3×24 jam kemudian disaring campuran tersebut dan diambil filtrat yang dihasilkan kemudian memasukan filtrat ke dalam 2 buah tabung reaksi masing-masing $5 \mathrm{~mL}$ lalu pada setiap tabung ditambahkan berturut-turut 5 $\mathrm{ml}$ larutan buffer $\mathrm{pH} 1$ dan tabung kedua memasukan larutan buffer $\mathrm{pH} 4.5$ setelah itu diukur absorbansi kedua tabung pada panjang gelombang berturut-turut $520 \mathrm{~nm}$ dan $700 \mathrm{~nm}$. Kemudian ditentukan kadarnya dengan rumus (Lee, dkk., 2005):

$$
\text { Total flavonoid }=\frac{\mathrm{A} \times \mathrm{Mr} \times 1000}{\varepsilon \times \mathrm{b}}
$$

dimana:

$$
\begin{aligned}
\mathrm{A} & =\text { Absorbansi total } \\
\mathrm{Mr}= & \text { Berat molekul sianidin-3Glukosida } \\
& \quad(449.2 \mathrm{~g} / \mathrm{mol}) \\
\mathrm{E} & =\text { Absorpsivitas molar sianidin }-3 \\
& \text { Glukosida }\left(26.000 \mathrm{~L} / \mathrm{mol} \mathrm{cm}^{-3}\right) \\
\mathrm{B} & =\text { Lebar kuvet }(1 \mathrm{~cm}) \\
1000= & \text { Faktor konversi dari gram kemiligram. }
\end{aligned}
$$

\section{Hasil dan Pembahasan}

\section{Kadar Air}

Penentuan kadar air suatu sampel dapat dilakukan dengan beberapa metode yaitu metode pengeringan/oven, metode destilasi, metode desikasi kimia dan metode khusus (NMR). Pada penelitian ini metode yang digunakan adalah metode pengeringan/oven. Dimana prisip pada metode ini yaitu air yang terkandung pada suatu bahan akan menguap pada suhu $105^{\circ} \mathrm{C}$ hingga berat konstan (Andarwulan, dkk., 2011).

Kadar air yang diperoleh pada sampel buah gambas muda yaitu $92.4195 \%$ dan gambas tua yaitu $86.6665 \%$. Analisis kadar air bertujuan untuk mengetahui seberapa besar kadar air yang 
terdapat pada buah gambas muda dan gambas tua yang akan kita analisis. Berdasarkan dari data yang diperoleh bahwa buah gambas muda lebih banyak mengandung air dibandingkan buah gambas yang tua. Hal ini karena selama proses pematangan buah terjadi perubahan dalam berbagai segi antara lain perubahan struktur, tekstur, warna, rasa dan proses biokimia yang terjadi didalamnya, lebih lanjut dijelaskan bahwa selama proses pematangan biasanya terjadi peningkatan jumlah gula dan rasa manis sebagai akibat dari degradasi polisakarida. Sedangkan pelunakan karena adanya hidrolisis dari polisakarida pada dinding sel (Abidin, 1991). Sehingga semakin tua suatu buah kadar patinya semakin rendah tetapi kadar glukosa, sukrosa, fruktosa serta maltosa semakin tinggi hal ini dikarenakan pada saat pati menuju proses pematangan pati tersebut terhidrolisis oleh air yang menjadi glukosa, sukrosa, sukrosa dan sebagian kecil maltosa. Akibatnya, semakin tua suatu buah gambas kadar airnya semakin rendah karena air tersebut digunakan untuk menghidrolisis pati.

\section{Kadar Flavonoid}

Flavonoid yaitu senyawa metabolit sekunder yang terdapat tanaman hijau kecuali alga yang berfungsi sebagai pigmen (pembentuk warna), pertahanan diri dari hama dan penyakit senyawa flavonoid juga digunakan dalam industri makanan sebagai pewarna makanan (Marhakam, 1988).

Analisis kadar flavonoid ini dapat ditentukan dengan menggunakan alat spektrofotometer UV-Vis pada panjang gelombang $520 \mathrm{~nm}$ dan $700 \mathrm{~nm}$. Pada penelitian ini sampel yang digunakan yaitu buah gambas (Luffa acutangula L). Pertama-tama sampel dibersihkan pada air mengalir lalu potong kecilkecil kemudian diangin-anginkan hingga kering pada suhu ruangan dan dihaluskan menggunakan blender. Tujuannya adalah agar zat-zat yang akan dianalisis dalam buah tersebut dapat secara maksimal dikeluarkan melalui proses ekstraksi, sampel yang telah halus selanjutnya dilarutkan ke dalam pelarut $\mathrm{HCl} \mathrm{1 \%} \mathrm{dalam} \mathrm{etanol.} \mathrm{Ekstraksi}$ yang dilakukan adalah ekstraksi maserasi dan dischaker dengan kecepatan $160 \mathrm{rpm}$ selama 1 jam. Ekstraksi maserasi digunakan karena metode ekstaksi ini sederhana dan tidak memerlukan alat khusus. Kecepatan pengadukan berpengaruh terhadap kadar flavonoid dimana kecepatan pengadukan yang rendah tidak mampu untuk menarik senyawa flavonoid dalam jaringan, namun jika kecepatan pengaduk terlalu besar berpotensi untuk merusak senyawa flavonoid yang telah diekstrak, sehingga menurunkan kadar senyawa flavonoid yang dihasilkan (Rajaei, dkk., 2010).)

Setelah sampel buah gambas (Luffa acutangula L) selesai dianalisis maka ditentukan kadarnya menggunakan metode $\mathrm{pH}$ deferensial dan diperoleh kadar flavonoid dalam satuan $(\mathrm{mg} / \mathrm{L})$ yang kemudian dikonversi menjadi (mg/100g). Kadar flavonoid yang diperoleh untuk gambas muda $10.60 \mathrm{mg} / 100 \mathrm{~g}$ sedangkan gambas tua sebanyak $2.62 \mathrm{mg} / 100 \mathrm{~g}$. Senyawa flavonoid yang sering ditemukan di bagian buah, yaitu antosianidin yang banyak diproduksi pada buah muda untuk melindungi buah dari sinar matahari dan serangga. Buah tua lebih banyak mengandung antosianin (turunan antosianidin) dibandingkan dengan antosianidin. Antosianin mengandung lebih banyak gula yang diproduksi untuk menarik serangga penyerbuk (Crozier, dkk., 2006).

Kandungan gula pada buah tua dapat meningkatkan berat kering ekstrak sehingga mengurangi kandungan total flavonoid pada jumlah yang sama dengan berat kering ekstrak buah muda. Oleh karena itu, kandungan total flavonoid ekstrak buah muda lebih tinggi dibandingkan dengan ekstrak buah tua pada jumlah sampel yang sama. (Syafitri, dkk., 2014). Senyawa flavonoid yang terkandung dalam buah merupakan hasil metabolisme sekunder yang ketika buah semakin tua maka akan terjadi biosintesis menjadi bentuk yang berbeda, sehingga dapat disarankan agar pemanfaatan buah yang potensial sebagai agen antioksidan dengan menggunakan buah yang masih muda (Rohyami, 2008).

Kadar flavonoid pada buah muda lebih banyak dibandingkan dengan buah tua, ini sesuai dengan penelitian yang dilakukan oleh Rohyami (2008) dan Syafitri, dkk. (2014). Dalam penelitian Rohyami (2008) tentang penentuan kandungan flavonoid dari ekstrak metanol daging buah mahkota dewa (Phaleria macrocarpa Scheff Boerl), yang menyatakan bahwa kandungan senyawa flavonoid pada buah tua rata-rata 2.2334 mg. $\mathrm{kg}^{-1}$ atau $0.004463 \%$ dan pada buah muda rata-rata adalah $2.7559 \mathrm{mg} . \mathrm{kg}^{-1}$ atau $0.005453 \%$. Kemudian dalam penelitian Syafitri, dkk. (2014) tentang kandungan fitokimia, total fenol, dan total flavonoid ekstrak buah Harendong (Melastoma affine D. Don), yang menyatakan bahwa total flavonoid tertinggi adalah ekstrak etanol buah muda sebesar $225.50 \mathrm{mg} / \mathrm{g}$ CE sedangkan buah tua sebesar $105.93 \mathrm{mg} / \mathrm{g}$ CE. Oleh karena itu disimpulkan bahwa buah harendong muda mengandung lebih banyak total flavonoid dibandingkan buah tua.

Analisis kadar flavonoid total pada buah patikala (Etlingera elatior (jack) R.M.SM) yaitu $1.7761 \mathrm{mgQE} / \mathrm{g}$ (Ahmad, dkk., 2015), pada buah kupa (Shyzigium polycepalum MIQ.) mengandung kadar flavonoid 6.06\% (Rahmiyani, 2017), sedangkan buah pare (Momordica charantia $L$ ) memiliki kadar flavonoid 1.712 mg/100g (Kusuma, 2012). Faktor yang mempengaruhi produksi metabolit sekunder yaitu komposisi media kultur, genetik, faktor fisik (suhu cahaya dan kelembapan) serta Perbedaan $\mathrm{pH}$ suatu daerah juga mempengaruhi perbedaan kadar flavonoid. Hal ini dikarenakan tanah yang 
memiliki $\mathrm{pH}$ yang rendah pada umumnya ditemui kekurangan zat hara mengakibatkan produktivitas juga rendah (Aristyanti, 2014).

Flavonoid merupakan golongan terbesar senyawa fenol alam dan merupakan senyawa polar karena mempunyai sejumlah gugus hidroksil, sehingga akan mudah larut dalam pelarut polar seperti etanol dan metanol (Arum, dkk., 2012). Flavonoid termasuk senyawa antioksidan yang mempunyai bioaktifitas sebagai alternatif pencegah radikal bebas, selain sebagai pencegah radikal bebas flavonoid juga merupakan senyawa polifenol yang memiliki fungsi sebagai senyawa antibakteri dengan cara membentuk senyawa kompleks terhadap protein ekstraseluler yang mengganggu integritas membran sel bakteri (Wijaya, dkk., 2014). Kelompok flavonoid yang banyak terdapat dialam yaitu flavon, flavonol dan antosianidin. Banyaknya senyawa flavonoid ini disebabkan oleh berbagai tingkat hidroksilasi, alkoksilasi atau glikosolasi dari struktur tersebut (Lenny, 2006).

\section{Kesimpulan}

Kadar flavonoid pada buah gambas ( Luffa acutangula L.) yang berasal dari Desa Posona Kabupaten Parigi Moutong yaitu gambas muda sebesar $10.60 \mathrm{mg} / 100 \mathrm{~g}$ dan gambas tua sebesar $2.62 \mathrm{mg} / 100 \mathrm{~g}$.

\section{Ucapan Terima Kasih}

Ucapan terimakasih penulis sampaikan kepada Tasrik, Husnia dan Nurbaya sebagai laboran dilaboratorium pendidikan kimia FKIP UNTAD yang telah memberikan masukan dan saran dalam melakukan penelitian, serta temanteman yang telah membantu dalam menyelesaikan penelitian ini.

\section{Referensi}

Abidin, Z. (1991). Dasar-dasar pengetahuan ilmu tanaman. Bandung: Angkasa.

Ahmad, A. R., Juwita, J., Ratulangi, S. A. D., \& Malik, A. (2017). Penetapan kadar fenolik dan flavonoid total ekstrak metanol buh dan daun patikala (etlingera elatior (jack) RM SM). Pharmaceutical Sciences and Research, 2(1), 1-10.

Andarwulan, N., Kusnandar, F., \& Herawati, D. (2011). Analisis pangan. Jakarta: Dian Rakyat.

Aristyanti, D. (2014). Pengaruh kadar kimia tanah terhadap kandungan flavonoid daun tabat barito (ficus deltoidea jack.). Skripsi Tidak Diterbitkan. Bogor: Institut Pertanian Bogor.

Arum, Y. P., Supartono, \& Sudarmin. (2012). Isolasi dan uji daya antimikroba ekstrak daun kersen (muntingia calabura). Jurnal MIPA, 35(2), 165-174.
Crozier A., Clifford M. N., \& Ashihara, H. (2006). Plant secondary metabolites: occurrence, structure, and role in the human diet. Lowa: Blackwell Publishing Ltd.

Jyothi, V., Ambati, S., \& Jyothi, A. V. (2010). The farmacognotic phytochemical and farmacological profile of luffa acutangula. Internasional Journal of Pharmacy and Thecnology, 2(4), 512-524.

Knekt, P., Kumpulainen, J., Jarvinen, R., Rissanen, H., Heliövaara, M., Reunanen, A., Hakulinen, T., \& Aromaa, A. (2002). Flavonoid intake and risk of chronic diseases. Journal of Clinical Nutrition, 76(3), 560-568.

Kusuma, P. (2012). Penetapan kadar flavonoid total dan daya antioksidan dari ekstrak etanol buah pare (momordica charantia l). Skripsi Tidak Diterbitkan. Makassar: UIN Alaudin.

Lee, J., Durst, R. W., \& Wrolstad, R. E. (2005). Determination of total monomeric anthocyanin pigmentcontent of fruit juices, beverages, naturalcolorants, andwines by the $\mathrm{pH}$ differential method: collaborative study. Journal of Association of Official Agricultural Chemist International, 88(5), 1269-1278.

Lenny, S. (2006). Senyawa flavonoid, fenilpropanoid, dan alkaloid. Diakses tanggal 22 Juni 2019 dari Website Universitas Sumatera Utara: http://repository.usu.ac.id/bitstream/handle/1 23456789/1842/06003489.pdf?sequence $=1$.

Marhakam, K. R. (1988). Cara mengidentifikasi flavonoid. Terjemahan Kosasih padmawinata. Bandung: ITB.

Menon, S., \& Satria, A. (2017). Mengkaji aktivitas antibakteri nasturtium opilea melastomoides terhadap escherchia coli. Jurnal Farmaka, 15(1), 63-69.

Rahmiyani, I. (2017). Penetapan kadar Flavonoid total ekstrak buah kupa (shyzigium polycepalum miq.) menggunakan spektrofotometri UV-Vis. Jurnal Kesehatan Bakti Tunas Husada, 17(2), 487-491.

Rajaei, A. M., Barzegar, Z., Hamidi, \& Sahari, M. A. (2010). Optimization of extraction conditions of phenolic compounds from pistachio (pictachia vera) green hull through response surface method. Journal of Agricultural Science and Technology, 12(1), 605-615.

Redha, A. (2010). Flavonoid: Struktur sifat antioksidan dan peranannya dalam sistem biologis. Jurnal Belian, 9(2), 196-202.

Rohyami, Y. (2008). Penentuan kandungan flavonoid dari ekstrak metanol daging buah mahkota dewa (phaleria macrocarpa scheff boerl). Jurnal Logika, 5(1), 1-16.

Sigit, J., Listyowati, R., Fitriana, Septyaningrum, H., Mahmudah, R. B., \& Purborini, N. (2016). 
Luffa acutangula sebagai alternatif penurun kadar glukosa darah. Jurnal Keperawatan Muhammadiyah, 1(1), 1-6.

Sudarmadji, S., Haryono, B., \& Suhardi. (1989). Analisis bahan makan dan pertanian. Yogyakarta: Liberty Yogyakarta.

Shrivastava, A., \& Roy, S. (2013). Cucurbitacae: A ethnomedicinally important vegetable family. Journal of Medicinal Plants Studies, 1(4), 16-20.

Syafitri, E. S., Bintang, M., \& Falah, S. (2014). Kandungan fitokimia, total fenol, dan total flavonoid ekstrak buah harendong (melastoma affine d. don). Jurnal Current Biochemistry, 1(3), 105-115.
Tristayanto. (2009). Studi aktifitas antibakteri dan identifikasi golongan senyawa ekstrak aktif antibakteri buah gambas (luffa acutangula roxb). Skripsi Tidak Diterbitkan. Surakarta: Universitas Sebelas Maret.

Voight, R. (1995). Buku pelajaran teknologi farmasi (Soedani Noerono Soewandi, Penerjemahan). Yogyakarta: Universitas Gajah Mada.

Winarsi, H. (2007). Antioksidan alami dan radikal bebas. Yogyakarta: Kanisius.

Wijaya, B. A., Citraningtyas, G., \& Wehantouw, F. (2014). Potensi ekstrak etanol tangkai daun talas colocasia esculenta (1) sebagai alternatif obat luka pada kulit kelinci (oryctolagus cuniculus). Jurnal Ilmiah Farmasi, 3(3), 1-9. 